\title{
Changes in properties of food proteins after interaction with free and $\beta$-cyclodextrin encapsulated hydroxycinnamic acids
}

\author{
Grażyna Budryn · Donata Zaczyńska • \\ Danuta Rachwał-Rosiak $\cdot$ Joanna Oracz
}

Received: 4 October 2014 / Revised: 14 January 2015 / Accepted: 17 January 2015 / Published online: 3 February 2015

(C) The Author(s) 2015. This article is published with open access at Springerlink.com

\begin{abstract}
Polyphenol-protein interactions during food processing may cause deterioration in protein nutritional quality status. This limits the possibility to enrich foods in phenolic preparations. The aim of this study was to assess whether encapsulation of hydroxycinnamic acids (HCAs) from green coffee extract (GCE) [using inclusion in $\beta$-cyclodextrin $(\beta-C D)]$ limits polyphenol-protein interactions. Three different protein isolates: egg white proteins, whey protein concentrate and soy protein isolate were exposed to interact with HCAs from GCE. After interactions, a higher increase in molecular mass and higher degradation of essential amino acids, as well as limitation of proteolytic digestion and solubility of proteins were reported, compared with the controls processed without HCAs. On the other hand, the interactions contributed to a higher radical-scavenging capacity in $\mathrm{DPPH}^{\circ}$ and $\mathrm{OH}^{\circ}$ assays and color deepening of proteins during processing. Inclusion of HCAs in $\beta$-CD cavity resulted in the limitation of the protein-HCA interactions, thus decreased the changes in nutritional and physicochemical properties. Adding HCAs in the form of inclusion complexes could be a promising solution for reducing unfavorable protein-polyphenol interactions during processing of foods enriched with phenolic acids.
\end{abstract}

Keywords Green coffee $\cdot$ Hydroxycinnamic acids . $\beta$-Cyclodextrin · Protein-polyphenol interactions . $\mathrm{LC}_{-\mathrm{MS}}$

G. Budryn $(\bowtie) \cdot$ D. Zaczyńska · D. Rachwał-Rosiak · J. Oracz Faculty of Biotechnology and Food Sciences, Institute of Chemical Food Technology, Lodz University of Technology, 90-924 Lodz, Poland

e-mail: grazyna.budryn@p.lodz.pl

\section{Introduction}

Modern food should have high nutritional value, attractive sensory characteristics and health-promoting properties. Therefore, it is not surprising that this type of food is often enriched with protein preparations that allow achieving high nutritional value and proper texture characteristics [1]. Furthermore, functional food is also often enriched with natural antioxidants, which have to protect ingredients from oxidation and additionally cause pro-healthy effects in human organism [2]. However, the combination of proteins and polyphenols in one product may cause various chemical interactions. As a consequence of those interactions, bioavailability or health-promoting properties of proteins and antioxidants can be reduced.

According to numerous studies hydroxycinnamic acids (HCAs) have multitude of health benefits. HCAs such as caffeic and ferulic acids, and their esters with quinic acid are one of the most important groups of phenolic compounds [3]. They have been shown to exhibit a broad range of biological activities including: antibacterial, antifungal, hepatoprotective, antithrombotic, anti-inflammatory, hypoglycemic and antioxidant [4-10]. In vivo antioxidant activity of HCAs reduces the risk of several oxidative stressrelated diseases, including atherosclerosis, some kinds of cancer and Alzheimer's disease [11-13]. Coffee is one of the plants that accumulate HCAs in quantities sufficient to have physiological effects. Green coffee beans are rich source of HCAs. They contain 4-10\% of these compounds [14]. Coffee bean extracts could be added to various kinds of food products, including those rich in proteins [15]. Previous studies have shown that this kind of combinations caused partial degradation of essential amino acids and reduced the susceptibility to proteolytic digestion [16, 17]. Therefore, it could be more beneficial to encapsulate 
HCAs by forming inclusion complexes with $\beta$-cyclodextrin $(\beta-C D)$ and to add them in this form to foods [18-20]. The aromatic ring of HCA located by inclusion inside the $\beta$-CD cavity can be protected against interactions. So far the limitation of interactions of polyphenol oxidase with inclusion complex of 5-caffeoylquinic acid (5-CQA) with $\beta$-CD was confirmed [21]. Inclusion of HCAs with $\beta-C D$ presumably does not limit their bioavailability and antioxidant activity [22].

The authors demonstrated lesser extent of food protein interactions with hydroxycinnamic acids from coffee encapsulated in $\beta-C D$ compared with free hydroxycinnamic acids that caused higher availability of the polyphenols for the digestive tract [23]. The aim of this study was to determine the extent to which encapsulation of HCAs from green coffee beans by inclusion in $\beta$-CD may limit the deterioration of food protein properties, caused by proteinHCA interactions.

\section{Materials and methods}

\section{Chemicals and raw materials}

Analytical-grade ethanol, ethyl acetate and $30 \%$ hydrogen peroxide were purchased from Poch (Gliwice, Poland), hydrochloric acid, sodium chloride, copper sulfate pentahydrate, potassium sodium tartrate tetrahydrate, potassium iodide, calcium carbonate, urea, sodium metabisulfite and sodium hydroxide from Chempur (Piekary Śląskie, Poland). HPLC-grade methanol, bovine serum albumin ( 99 \%), phenol, $\beta$-cyclodextrin $(\beta-\mathrm{CD}, \geq 98 \%)$ and 2,2-diphenyl1-picrylhydrazyl (DPPH') were purchased from Fluka (St. Louis, MO, USA), 5-caffeoylquinic acid (5-CQA, 99 \%), caffeic acid (CA, 99 \%), ferulic acid (FA, 99 \%), pep$\sin (\sim 99 \%)$, trypsin ( 99\%), chymotrypsin ( 99\%), sodium phosphate monobasic dihydrate $(\sim 99 \%)$, sodium phosphate dibasic dodecahydrate ( 99 \%), iron (II) sulfate ( 98 \%), sodium salicylate $(\sim 98 \%)$ and tris-hydrochloric acid ( 98 \%) from Sigma-Aldrich (St. Louis, MO, USA), acetate buffer $\mathrm{pH} 2.20$, phosphate buffer $\mathrm{pH} 6.45$ and set of reagents for amino acids analysis from BioChrom (Cambridge, UK), and nylon filters from Chromacol (Herts, UK). Ultrapure water (resistivity, $18.2 \mathrm{M} \Omega \mathrm{cm}$ ) was obtained from a Millipore Milli-Q Plus purification system (Bedford, MA, USA).

Green robusta coffee beans (Coffea canephora L.) harvested in Brazil in 2012, dehulled by dry method were purchased from Bero Polska (Gdynia, Poland). Protein isolates: whey protein concentrate (WPC, protein content (pc) $873 \mathrm{~g} \mathrm{~kg}^{-1}$, lactose $56 \mathrm{~g} \mathrm{~kg}^{-1}$, ash $22 \mathrm{~g} \mathrm{~kg}^{-1}$ ) from Bartex (Pasłęk, Poland), egg white proteins (EWP, pc $892 \mathrm{~g} \mathrm{~kg}^{-1}$, fat $1 \mathrm{~g} \mathrm{~kg}^{-1}$, ash $51 \mathrm{~g} \mathrm{~kg}^{-1}$ ) from Basso (Gołkowice,
Poland) and soy protein isolate (SPI, pc $905 \mathrm{~g} \mathrm{~kg}^{-1}$, fiber $2 \mathrm{~g} \mathrm{~kg}^{-1}$, ash $40 \mathrm{~g} \mathrm{~kg}^{-1}$ ) from Gushen (Pabianice, Poland) were used for interactions with HCAs.

Preparation and purification of green coffee extract (GCE)

The aqueous extract was obtained as previously described [14]. The extract contained isomers of caffeoylquinic, feruloylquinic and dicaffeoylquinic acids. The solution was frozen at $-80^{\circ} \mathrm{C}$, freeze-dried in a DELTA 1-24LSC Christ freeze drier (Osterode am Harz, Germany) and purified. To purify GCE, the centrifugal partition chromatography (CPC) method was used with SPOT Prep II 50 chromatograph from Armen Instrument (Saint-Avé, France) integrated with UV/Vis detector and a fraction collector. Briefly, the two-phase system of solvents was prepared from water, ethanol and ethyl acetate (5:1:4, $\mathrm{v} / \mathrm{v} / \mathrm{v})$. Elution of HCAs occurred from 20 to $24 \mathrm{~min}$ and from 29 to $32 \mathrm{~min}$ of the analysis, detected by UV absorption at $320 \mathrm{~nm}$. Collected fractions were concentrated in ScanMaxiVac Labogene (Lynge, Denmark) concentrator and again freeze-dried. The content of HCAs in purified GCE was $564.8 \mathrm{~g} \mathrm{~kg}^{-1} \mathrm{db}$. (dry basis) and caffeine was eliminated. The remainder of the extract was proteins (29.5 $\mathrm{g} \mathrm{kg}^{-1} \mathrm{db}$.), sugars $\left(92.8 \mathrm{~g} \mathrm{~kg}^{-1} \mathrm{db}\right.$.), soluble fiber (121.6 $\mathrm{g} \mathrm{kg}^{-1} \mathrm{db}$.) and minerals (191.3 $\mathrm{g} \mathrm{kg}^{-1} \mathrm{db}$.).

Preparation of inclusion complexes of $\beta$-CD with HCAs from GCE ( $\beta$-CD-HCAs)

Inclusion complexes of $\beta$-CD with HCAs were prepared with average molar ratio of substrates 1:2 (calculated based on molar mass of 5-CQA) in the reaction solution of substrates to maximize the efficacy of complexation [14]. Therefore, $0.1135 \mathrm{~g}$ of $\beta-\mathrm{CD}$ and $0.1303 \mathrm{~g}$ of GCE, which contained $0.0708 \mathrm{~g}$ of HCAs were dissolved in $2 \mathrm{~mL}$ of water. The complexation was conducted for $2 \mathrm{~h}$ at $50{ }^{\circ} \mathrm{C}$ in a Pierce Reacti-Therm TS-18821 reactor from Thermo Scientific (Palo Alto, CA, USA). After complexation, the solution was left for $24 \mathrm{~h}$ at $0{ }^{\circ} \mathrm{C}$ and the suspension was centrifuged in MIKRO 22R centrifuge from Hettich (Kirchlengern, Germany) at $4{ }^{\circ} \mathrm{C}$ for $20 \mathrm{~min}$ at $10,000 \times g$. A mixture of $\beta$-CD complexes with particular HCAs was obtained and characterized by ESI-MS/MS method [14]. The molar ratio of $\beta-\mathrm{CD}$ and HCAs in complexes was 1:1.

Interactions of HCAs with proteins

A $0.10-\mathrm{g}$ sample of WPC, EWP or SPI and $0.015 \mathrm{~g}$ of HCAs contained in $0.028 \mathrm{~g}$ of GCE or in $0.075 \mathrm{~g}$ of $\beta-\mathrm{CD}$ HCA complexes were dissolved in $3 \mathrm{~mL}$ of phosphate buffer $\mathrm{pH} 6.45$. Proteins $(0.10 \mathrm{~g})$ were additionally reacted with $0.01 \mathrm{~g}$ of standards: 5-CQA, CA or FA. The solutions 
were reacted for $1.5 \mathrm{~h}$ at 25 or $90{ }^{\circ} \mathrm{C}$ in a Pierce ReactiTherm TS-18821 reactor and dialyzed in micro dialyzer against cellulose membrane from Harvard Apparatus (Holliston, MA, US) to remove molecules $\leq 1.5 \mathrm{kDa}$ and then freeze-dried [23].

\section{Molecular mass analysis}

A 5-mg sample of protein was dissolved in $1 \mathrm{~mL}$ of phosphate buffer ( $\mathrm{pH}$ 6.8) obtained by dissolving monobasic sodium phosphate dihydrate and dibasic sodium phosphate dodecahydrate. HPLC analysis was conducted at $25{ }^{\circ} \mathrm{C}$ with isocratic elution using phosphate buffer $\mathrm{pH} 6.8$ [24]. Liquid chromatograph (UHPLC) UltiMate 3000 Dionex (Sunnyvale, CA, USA), equipped with UV/DAD detector and gel column Yarra SEC-3000 $(3,000 \times 7.8 \mathrm{~mm}, 3 \mu \mathrm{m})$ from Phenomenex (Torrance, CA, USA) was used. Detection was performed at $280 \mathrm{~nm}$. The injection volume was $10 \mu \mathrm{L}$, and the flow rate was $1.0 \mathrm{~mL} \mathrm{~min}^{-1}$. To calculate the molecular mass, we used standard mixture of proteins. The mixture contained bovine thyroglobulin $(670 \mathrm{kDa})$, globu$\operatorname{lin}[\operatorname{IgA}(300 \mathrm{kDa})+\operatorname{IgG}(150 \mathrm{kDa})]$, ovalbumin $(44 \mathrm{kDa})$, myoglobin $(17 \mathrm{kDa})$ and uridine $(244 \mathrm{Da})$, purchased from Phenomenex (Torrance, CA, USA). Molecular masses were calculated based on the chromatogram of standard solution. For this purpose, an equation was obtained based on logarithmic curve of the molecular mass of each standard component related to its individual elution time divided by the elution time of the first component (thyroglobulin). The analysis was also performed after proteolytic digestion.

Essential amino acids profile determination

The analysis was performed according to the Commission Directive 98/64/EC [25]. Oxidative solution in volume of $0.5 \mathrm{~mL}(0.05 \mathrm{~mL}$ of $30 \%$ hydrogen peroxide with $0.45 \mathrm{~mL}$ of formic acid solution ( $8.89 \mathrm{~g}$ of formic acid, $0.47 \mathrm{~g}$ of phenol and $11.1 \mathrm{~g}$ of water)) was added to $10 \mathrm{mg}$ of proteins. Labile amino acids such as methionine and cysteine were fully oxidized to methionine sulfone and L-cysteic acid, respectively. Then, $0.084 \mathrm{~g}$ of sodium metabisulfite was added to remove an excess of oxidizing agent. Subsequently, $2.5 \mathrm{~mL}$ of hydrolysis solution $(49.2 \mathrm{~mL}$ of $37 \%$ hydrochloric acid, $1 \mathrm{~g}$ of phenol and water to $100 \mathrm{ml}$ ) was added and kept at $104{ }^{\circ} \mathrm{C}$ for $24 \mathrm{~h}$. Next, $1 \mathrm{~mL}$ of $40 \%$ sodium hydroxide was added followed by acetate buffer pH 2.20 to a volume of $5 \mathrm{~mL}$. An aliquot of the resulting solution was diluted five times with acetate buffer $\mathrm{pH}$ 2.2 and filtered through a $0.2-\mu \mathrm{m}$ nylon filter. Chromatographic analysis was carried out using an amino acid analyzer Biochrom 30+ with oxidized feedstuff column, with post-column ninhydrin detection. Volume of injection was $20 \mu \mathrm{L}$. Amino acids elution using set of buffers was as follows: at $56{ }^{\circ} \mathrm{C}$ : $5 \mathrm{~min}$ at $\mathrm{pH} 2.65$ and $19.5 \mathrm{~min}$ at $\mathrm{pH} 3.35$, then at $58^{\circ} \mathrm{C}: 21.5 \mathrm{~min}$ at $\mathrm{pH} 4.25$ and $1 \mathrm{~min}$ at $\mathrm{pH} 8.6$, next at $68{ }^{\circ} \mathrm{C}: 18 \mathrm{~min}$ at $\mathrm{pH} 8.6$ and finally at $94{ }^{\circ} \mathrm{C}: 25$ min at pH 8.6 and 4 min with $20 \% \mathrm{NaOH}$ and ninhydrin. The flow rate during the whole analysis was $0.4 \mathrm{~mL} \mathrm{~min}^{-1}$.

Proteolytic digestibility analysis

Proteolytic digestion was performed according to Rawel et al. [24]. A 6-mg sample of protein was dissolved in $1.5 \mathrm{~mL}$ of $\mathrm{pH} 2.0$ buffer $(0.3 \mathrm{~mL}$ of $37 \%$ hydrochloric acid, $12 \mathrm{~mL}$ of $1 \mathrm{M}$ urea and water to $100 \mathrm{~mL}$ ) and $100 \mu \mathrm{L}$ of pepsin $\left(1 \mathrm{mg} \mathrm{mL}^{-1}\right)$ was added. Samples were incubated for $2 \mathrm{~h}$ at $36^{\circ} \mathrm{C}$. After this step, $0.27 \mathrm{~mL}$ of $5 \%$ sodium hydroxide was added. The samples were frozen and then freeze-dried. Subsequently, $1.5 \mathrm{~mL}$ of $\mathrm{pH} 8.2$ buffer (0.02 M calcium carbonate, $2 \mathrm{M}$ urea, $0.1 \mathrm{M}$ tris-hydrochloric acid $\mathrm{pH} 8)$ together with $100 \mu \mathrm{L}\left(1 \mathrm{mg} \mathrm{mL}^{-1}\right)$ of both trypsin and chymotrypsin were added. Prepared samples were re-incubated for $24 \mathrm{~h}$ at $36{ }^{\circ} \mathrm{C}$ and then frozen and freeze-dried.

\section{Radical-scavenging capacity}

Scavenging capacity against $\mathrm{DPPH}{ }^{\bullet}$ radical was determined according to MacDonald-Wicks et al. [26] with some modifications. The test was carried out using protein solutions in phosphate buffer $\mathrm{pH} 6.8$ at concentrations of 10, 25, 50 and $100 \mathrm{mg} \mathrm{mL}^{-1}$. Next, $0.1 \mathrm{~mL}$ of protein solution was reacted with $3.9 \mathrm{~mL}$ of methanolic radical solution $\left(50 \mu \mathrm{g} \mathrm{mL}^{-1}\right)$. Methanol was used as a blank sample and $0.1 \mathrm{~mL}$ of $\mathrm{pH} 6.8$ buffer with $3.9 \mathrm{~mL}^{\circ}$ of methanolic $\mathrm{DPPH}^{*}$ solution as a control. Based on the measurement of absorbance at $517 \mathrm{~nm}$ of a tested sample $\left(A_{\text {test }}\right)$ and control $\left(A_{\text {control }}\right)$ after $30 \mathrm{~min}$ [UV/Vis spectrophotometer U-2800 A Hitachi (Tokyo, Japan)], a calibration curve of protein concentration versus $\mathrm{DPPH}^{*}$ radical-scavenging capacity and its regression equation were obtained. $\mathrm{DPPH}^{-}$radical-scavenging capacity $A A \%=\left[\left(A_{\text {control }}-A_{\text {test }}\right) / A_{\text {control }}\right] \times 100 \%$.

Hydroxyl radical-scavenging capacity of protein solutions in phosphate buffer $\mathrm{pH} 6.8$ was performed according to Sudha et al. [27]. Briefly $1 \mathrm{~mL}$ of $1.5 \mathrm{mM}$ iron (II) sulfate was combined with $0.7 \mathrm{~mL}$ of $6 \mathrm{mM}$ hydrogen peroxide and $0.3 \mathrm{~mL}$ of $20 \mathrm{mM}$ sodium salicylate. Samples were incubated for $1 \mathrm{~h}$ at $37{ }^{\circ} \mathrm{C}$, and the absorbance of hydroxylated salicylate complex was measured at $562 \mathrm{~nm}$. $\mathrm{OH}^{*}$ radical-scavenging capacity $A A \%=\left[1-\left(A_{1}-A_{2}\right) / A_{0}\right]$ $\times 100$, where $A_{0}$ is the absorbance of the control (without proteins), $A_{1}$-in the presence of protein, and $A_{2}$-without sodium salicylate. 


\section{CIE $L^{*} a^{*} b^{*}$ color determination}

Color measurements in CIE $L^{*} a^{*} b^{*}$ system were performed using an automatic colorimeter Konica Minolta CR-400 with Spectra Magic NX 1.3 software (Osaka, Japan). Color parameters, i.e., $L^{*}$ (from 0 -black to 100 white), $a^{*}$ [from $(-50)$-green to 50 -red] and $b^{*}$ [from (-50) - blue to 50-yellow] were measured [28].

\section{Protein solubility}

The solubility of proteins was determined by the biuret method by dissolving in $0.9 \%$ sodium chloride $\left(1 \mathrm{mg} \mathrm{mL}^{-1}\right.$ ) [24]. To $1 \mathrm{~mL}$ of the protein solution, $4 \mathrm{~mL}$ of biuret reagent ( $1.5 \mathrm{~g}$ of copper sulfate, $6.9 \mathrm{~g}$ of potassium sodium tartrate, $300 \mathrm{ml}$ of $10 \%$ sodium hydroxide and $2 \mathrm{~g}$ of potassium iodide filled up to $1 \mathrm{~L}$ with water) was added. Absorbance was measured after $30 \mathrm{~min}$ at $540 \mathrm{~nm}$. As a reference, a sample without protein was prepared. A calibration curve was obtained using bovine serum albumin dissolved in $0.9 \%$ sodium chloride.

\section{Statistical analysis}

The protein-HCA interactions were conducted twice. Analyses were carried out in triplicate for both replicates, and their results were subjected to statistical analysis. It comprised determination of average values of six measurements and their standard deviation as well as one-way ANOVA (analysis of variation) using Statistica 10.0 software at the significance level $p<0.05$.

\section{Results and discussion}

Molecular mass and proteolytic digestion susceptibility of proteins after interactions with HCAs

Three different commercial protein isolates were interacting with HCAs from green coffee beans. HCAs were used in a form of purified GCE and $\beta$-CD-HCAs. The interactions were additionally carried out with standards of HCAs, i.e., CA, 5-CQA and FA. Report on molecular mass changes in proteins as a result of interactions with HCAs was obtained with the use of HPLC-UV/DAD method. Examples of obtained chromatograms are presented in Figs. 1, 2 and 3a, b, wherein (a) represents the chromatograms of unmodified EWP, WPC and SPI and (b) after heating with HCAs form GCE at $\mathrm{pH} 6.45$ and $90{ }^{\circ} \mathrm{C}$. Average molecular mass (AMM, Table 1) was calculated from molecular mass corresponding to the recorded peaks and their share in the total peak area. Unmodified proteins showed AMM of 50, 29 and $191 \mathrm{kDa}$, respectively, for
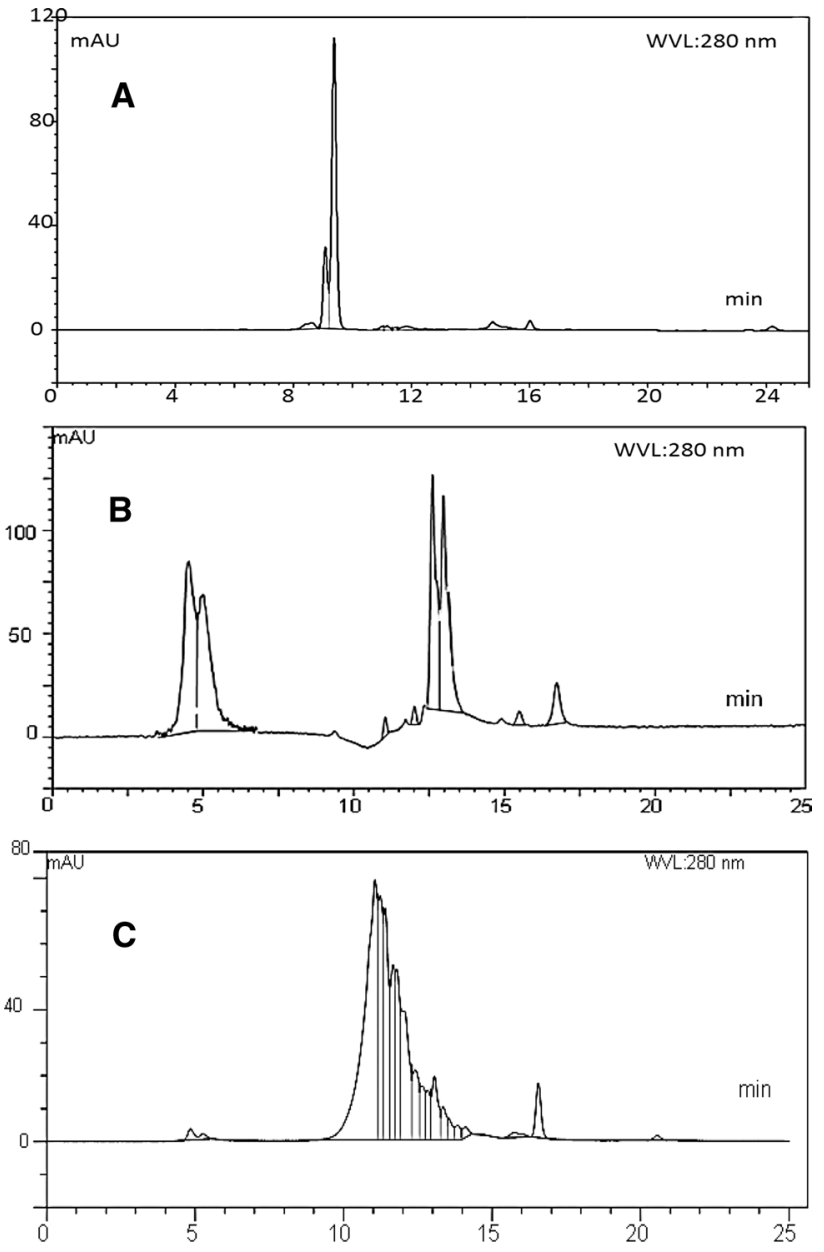

Fig. 1 HPLC gel-filtration chromatogram of egg white proteins a unmodified, b interacted at $\mathrm{pH} 6.45$ and $90{ }^{\circ} \mathrm{C}$ with hydroxycinnamic acids from green coffee extract and $\mathbf{c}$ interacting as previously and proteolysed

EWP, WPC and SPI. Proteins that were modified without heating showed AMM increase of maximum $376 \%$ (from 191.22 to $910.63 \mathrm{kDa}$; SPI $+\mathrm{GCE}, 25^{\circ} \mathrm{C}$ ) (Table 1). For proteins exposed to temperature of $90{ }^{\circ} \mathrm{C}$ without HCAs AMM increase of 342, 386 and $677 \%$ for EWP (from 49.76 to $220.13 \mathrm{kDa}$ ), SPI (from 191.22 to $930.25 \mathrm{kDa}$ ) and WPC (from 28.87 to $224.34 \mathrm{kDa}$ ) was observed, respectively. However, after heating of proteins together with HCAs, a much greater AMM growth of $465 \%$ (from 191.22 to $1,080.36 \mathrm{kDa}$ for SPI $+\beta$-CD-HCAs) to $3,974 \%$ (from 49.76 to $1,937.82$ for EWP + 5-CQA) was reported. The large products of interactions were formed as a result of aggregation or cross-linking as it was shown by Faergemant et al. [29] and Rawel et al. [30]. From the above, it could be concluded that higher temperature promoted the intensity of interactions between the proteins and polyphenols carried out at $\mathrm{pH} 6.45$ [17]. HCAs inclusion in the $\beta-\mathrm{CD}$ molecule resulted in limitation of AMM increase 

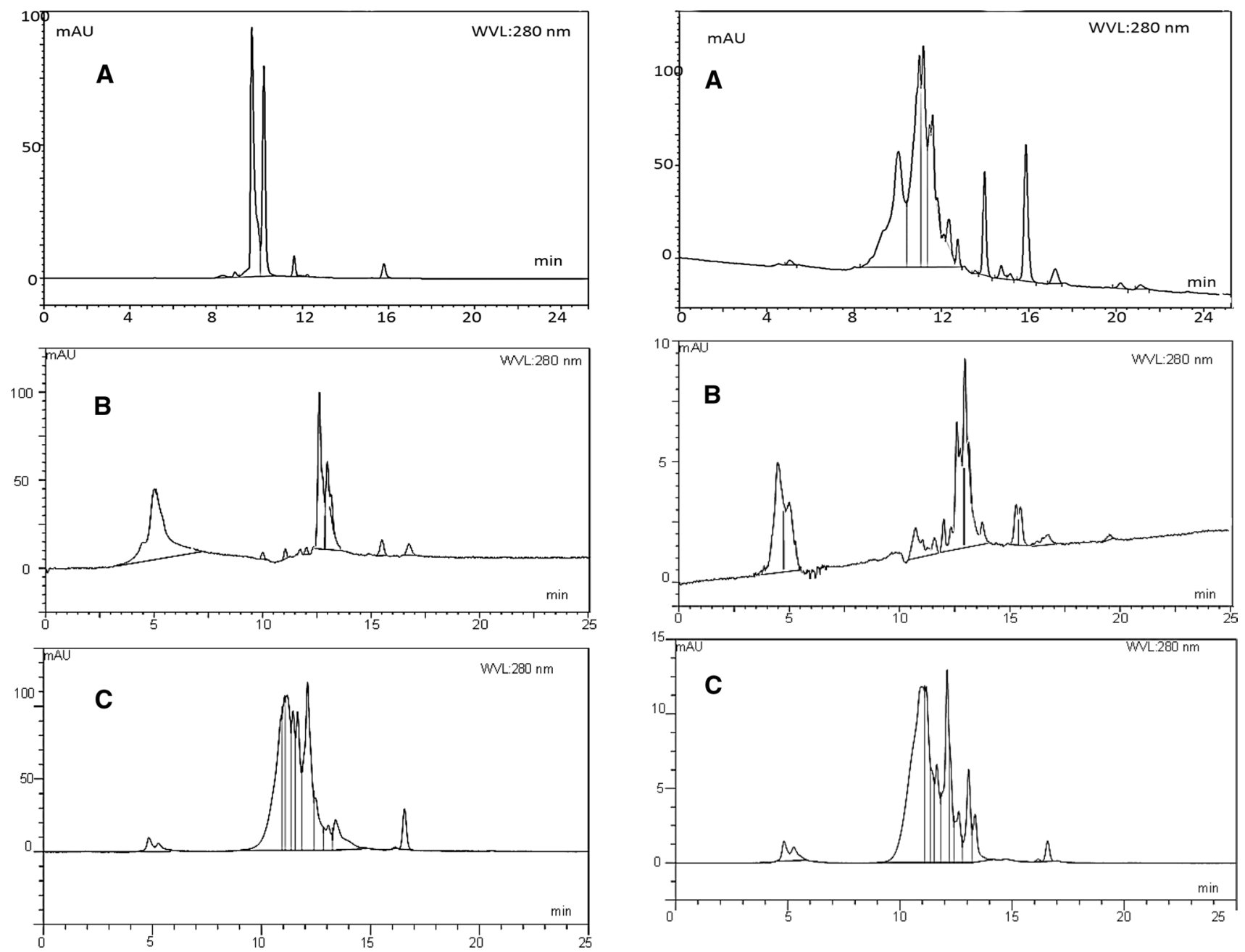

Fig. 2 HPLC gel-filtration chromatogram of whey proteins concentrate a unmodified, $\mathbf{b}$ interacted at $\mathrm{pH} 6.45$ and $90{ }^{\circ} \mathrm{C}$ with hydroxycinnamic acids from green coffee extract and $\mathbf{c}$ interacting as previously and proteolysed

compared with proteins heated with free HCAs. For this option, AMM was on the similar level as for proteins heated without HCAs and statistically lower $(p<0.05)$ than for proteins heated with free HCAs. The increase in protein AMM for different kinds of isolates followed in order: SPI $<$ WPC $<$ EWP, so in opposite order than the initial AMM. Such relation was caused by the fact that initial high value of molecular mass (for SPI) resulted in relatively small protein surface, on which the interactions take place [23]. Different forms of HCAs preparations showed their impact on AMM increase in the following order: $\beta$-CDHCAs $<$ FA $<$ CA $<$ GCE $<$ 5-CQA. Therefore, methoxylation of one of the hydroxyl groups on FA phenolic ring compared with CA limited interactions with proteins. On the contrary, quinic acid moiety in 5-CQA intensified interactions related to the AMM increase. Similar observation was made by Rawel et al. [24].

Fig. 3 HPLC gel-filtration chromatogram of soy protein isolate a unmodified, b interacted at $\mathrm{pH} 6.45$ and $90{ }^{\circ} \mathrm{C}$ with hydroxycinnamic acids from green coffee extract and $\mathbf{c}$ interacting as previously and proteolysed

The profile of molecular mass of each digested protein was analyzed by HPLC-UV/DAD method and examples of chromatograms are presented in Figs. 1, 2 and 3c. Aggregation or cross-linking affected digestion of proteins. For proteins after digestion, the lowest AMM was reported for unmodified EWP, SPI and WPC and it amounted about 5, 4, and $6.5 \mathrm{kDa}$, respectively (Table 1). Processing of proteins without HCAs contributed to AMM increase after digestion of 7-99 \% (from 6.09 to $6.51 \mathrm{kDa}$ for SPI at $25{ }^{\circ} \mathrm{C}$ and from 3.14 to $6.26 \mathrm{kDa}$ for $\mathrm{WPC}$ at $90{ }^{\circ} \mathrm{C}$, respectively). When the process was carried with HCAs at ambient temperature, AMM for digested SPI was statistically at the same level $(p<0.05$ ), (decreased from 6.09 to $5.87 \mathrm{kDa}$ ) and for EWP and WPC increased by $80 \%$ (from 3.19 to $5.76 \mathrm{kDa}$ and from 3.14 to $5.65 \mathrm{kDa}$, respectively). This indicates that agglomerated and cross-linked protein molecules are less accessible for enzymes [30]. Additionally, binding of HCAs to hydrophobic amino acids that are cleaved during 


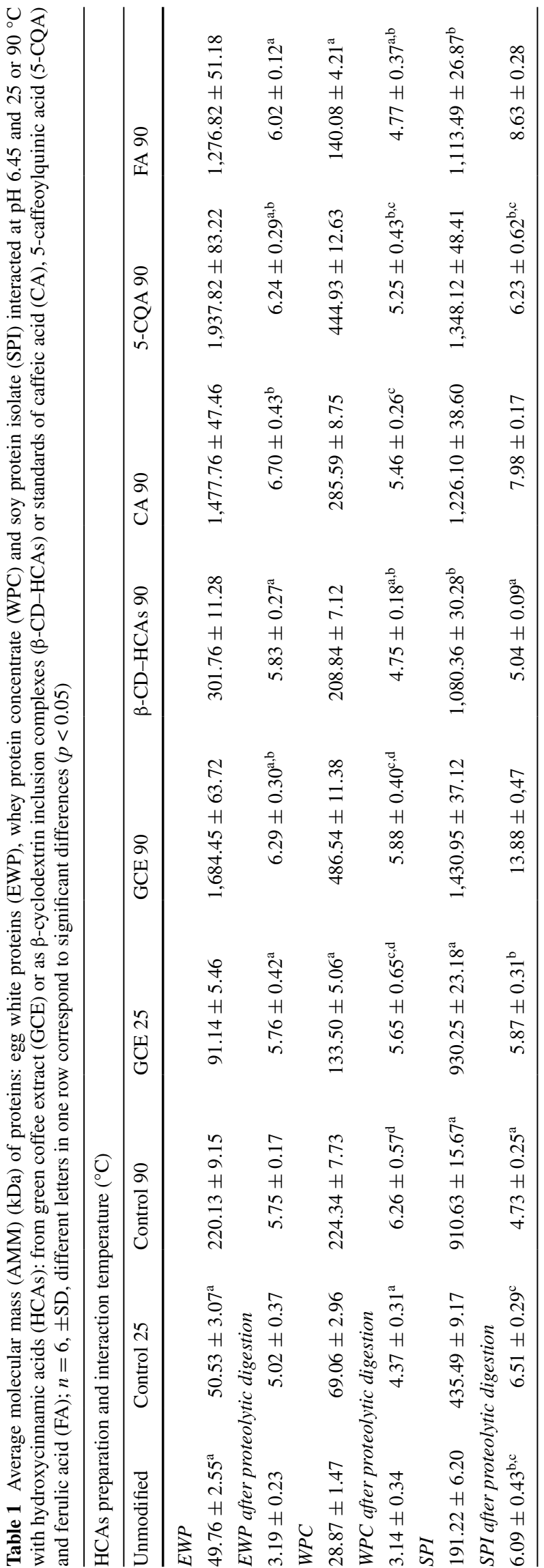

digestion by pepsin, limits availability of nearest peptide bonds for enzyme [31]. Furthermore, proteolytic enzymes themselves could interact with HCAs, what decreases their activity [32, 33]. For SPI, greater efficacy of proteolytic digestion may be due to conformational changes caused by interactions with HCAs and exposure of hydrophobic amino acids [34]. Heating of proteins with HCAs contributed to changes in AMM of digested proteins in the range from $-17 \%$ (from 6.09 to $5.04 \mathrm{kDa}$ ) for SPI $+\beta$-CDHCAs to $128 \%$ (from 6.09 to $13.88 \mathrm{kDa}$ ) for SPI + GCE. Taking into consideration protein type, AMM after digestion increased in the following order: SPI $<$ WPC $<$ EWP, while in the relation to HCAs form, the increase in AMM was as follows: $\beta$-CD-HCAs $<$ FA $<5$-CQA $<$ CA $<$ GCE. Alike for result of this study greater limitation of the proteolytic digestion by CA compared to 5-CQA observed Rawel et al. [35].

Amino acids profile of proteins after interactions with HCAs

The profile of essential amino acids was analyzed after hydrolysis with hydrochloric acid. Total amino acids were also determined to give insight on the overall amino acids changes. In unmodified proteins, the content of essential as well as total amino acids increased in the following order: SPI $<$ EWP $<$ WPC (Table 2). The analysis showed losses of the essential and total amino acids as a result of processing. These losses were increased in the presence of HCAs during modification due to stable HCAs binding to amino, thiol and phenolic moieties [36]. The used protocol of amino acids determination caused complete degradation of tryptophan, which was not reported in the mixture of amino acids after hydrolysis. However, the interactions of tryptophan with HCAs caused its protection during hydrolysis, and hence some amounts were determined in the proteins processed with HCAs. In general, the greatest losses were observed for methionine, followed by valine and isoleucine. The influence of HCAs preparation form on essential amino acids losses increased in order: $\beta-\mathrm{CD}-$ HCAs $<5$-CQA $<$ FA $<$ CA $<$ GCE. Therefore, inclusion of HCAs in the $\beta$-CD had a beneficial effect on the retention of essential and total amino acids during processing. Comparing the three analyzed proteins, average loss of essential amino acids increased in order: SPI $<$ EWP $<$ WPC, so in the case of the analyzed isolates, the greater the initial content of essential amino acids was, the bigger the losses during processing.

Radical-scavenging capacity of proteins after interactions with HCAs

Products of EWP, SPI and WPC interactions with HCAs were analyzed on $\mathrm{DPPH}^{\cdot}$ and $\mathrm{OH}^{-}$radicals scavenging capacity. 


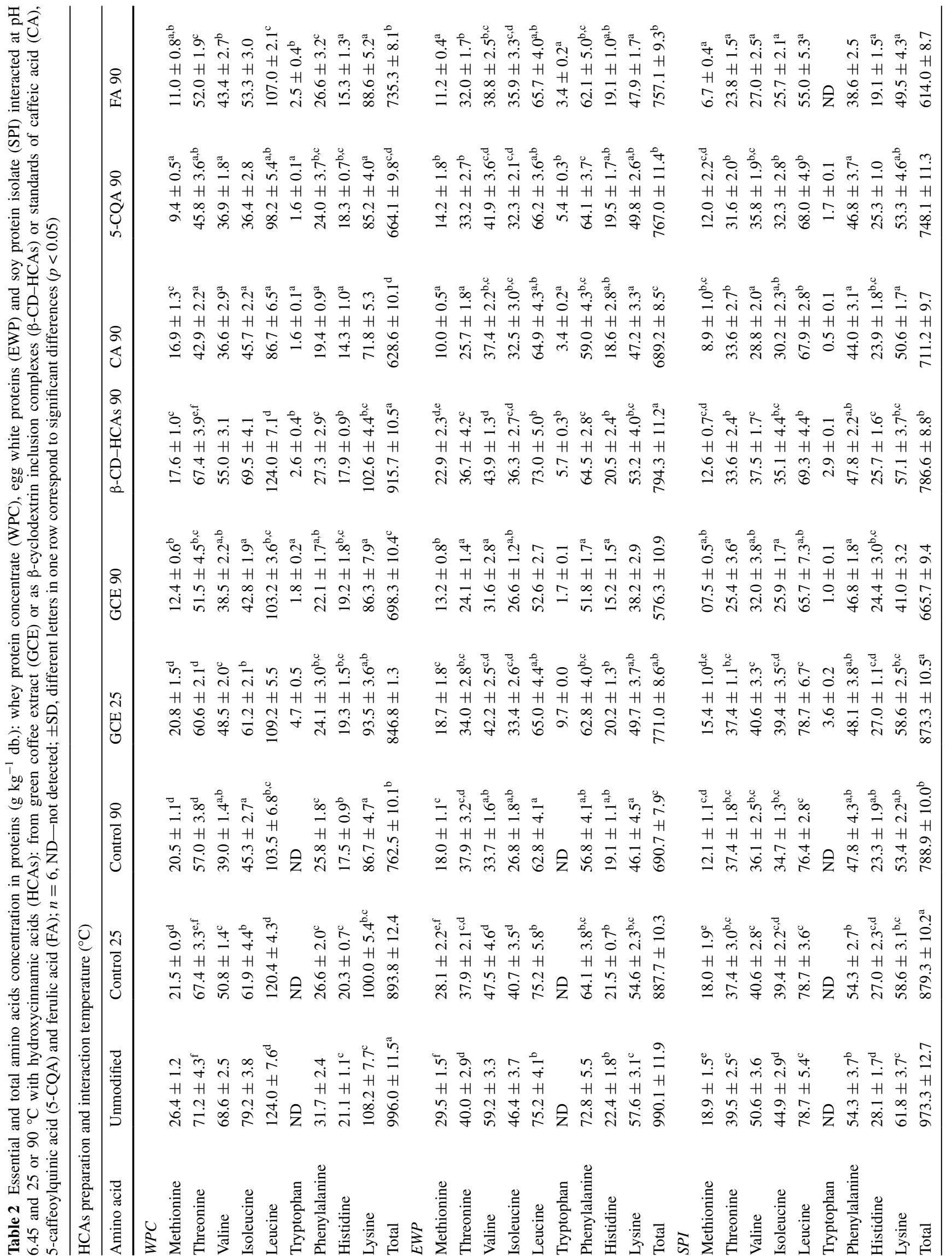


Table 3 Radical-scavenging capacity, color and solubility of proteins: egg white proteins (EWP), whey protein concentrate (WPC) and soy protein isolate (SPI) interacted at $\mathrm{pH} 6.45$ and 25 or $90{ }^{\circ} \mathrm{C}$ with hydroxycinnamic acids (HCAs): from green coffee extract
(GCE) or as $\beta$-cyclodextrin inclusion complexes ( $\beta$-CD-HCAs) or standards of caffeic acid (CA), 5-caffeoylquinic acid (5-CQA) and ferulic acid (FA); $n=6, \pm \mathrm{SD}$, different letters in one column correspond to significant differences $(p<0.05)$

\begin{tabular}{|c|c|c|c|c|c|c|c|}
\hline \multirow[t]{2}{*}{ Protein } & \multirow{2}{*}{$\begin{array}{l}\text { HCAs preparation } \\
\text { and temperature of } \\
\text { interactions }\left({ }^{\circ} \mathrm{C}\right)\end{array}$} & \multicolumn{2}{|c|}{ Radical-scavenging capacity (\%) } & \multicolumn{3}{|c|}{ CIE $L^{*} a^{*} b^{*}$ coordinates } & \multirow[t]{2}{*}{ Solubility (\%) } \\
\hline & & $\mathrm{DPPH}^{\cdot}$ & $\mathrm{OH}^{\cdot}$ & $L^{*}$ & $a^{*}$ & $b^{*}$ & \\
\hline \multirow[t]{9}{*}{ EWP } & Unmodified & $71.98 \pm 6.45^{\mathrm{k}}$ & $81.96 \pm 6.15^{\mathrm{j}, \mathrm{k}}$ & $96.07 \pm 8.17^{\mathrm{h}}$ & $-2.97 \pm 0.18$ & $17.61 \pm 1.15^{\mathrm{e}, \mathrm{f}}$ & $100.82 \pm 4.13^{\mathrm{j}}$ \\
\hline & Control 25 & $68.78 \pm 5.30^{\mathrm{k}}$ & $76.90 \pm 5.65^{\mathrm{i}, \mathrm{j}}$ & $92.49 \pm 5.28^{\mathrm{g}, \mathrm{h}}$ & $-1.90 \pm 0.10$ & $11.11 \pm 0.97^{\mathrm{c}, \mathrm{d}}$ & $98.16 \pm 2.28^{\mathrm{j}}$ \\
\hline & Control 90 & $20.55 \pm 1.90^{\mathrm{d}, \mathrm{e}}$ & $38.83 \pm 2.80^{\mathrm{e}, \mathrm{f}}$ & $85.76 \pm 7.71^{\mathrm{e}, \mathrm{f}}$ & $-0.15 \pm 0.08^{\mathrm{b}}$ & $7.95 \pm 0.66^{\mathrm{a}}$ & $37.39 \pm 1.55^{\mathrm{g}, \mathrm{h}}$ \\
\hline & GCE 25 & $94.19 \pm 7.13$ & $97.15 \pm 7.03^{\mathrm{k}}$ & $90.83 \pm 6.59^{\mathrm{f}, \mathrm{g}}$ & $-0.36 \pm 0.21^{\mathrm{b}}$ & $8.17 \pm 0.58^{\mathrm{a}}$ & $91.17 \pm 3.16$ \\
\hline & GCE 90 & $27.30 \pm 1.43^{\mathrm{g}, \mathrm{h}}$ & $40.88 \pm 3.98^{\mathrm{f}}$ & $79.24 \pm 5.52^{\mathrm{d}, \mathrm{e}}$ & $1.96 \pm 0.17^{\mathrm{d}}$ & $15.70 \pm 0.96^{\mathrm{e}, \mathrm{f}}$ & $24.82 \pm 1.17^{\mathrm{e}, \mathrm{f}}$ \\
\hline & $\beta$-CD-HCAs 90 & $22.17 \pm 1.85^{\mathrm{e}, \mathrm{f}}$ & $37.19 \pm 2.26^{\mathrm{e}, \mathrm{f}}$ & $86.08 \pm 6.50^{\mathrm{e}, \mathrm{f}}$ & $-0.67 \pm 0.04$ & $8.56 \pm 0.64^{\mathrm{a}, \mathrm{b}}$ & $35.79 \pm 1.96^{\mathrm{g}}$ \\
\hline & CA 90 & $29.90 \pm 2.18^{\mathrm{g}, \mathrm{h}}$ & $45.75 \pm 3.18^{\mathrm{g}}$ & $82.42 \pm 7.02^{\mathrm{d}, \mathrm{e}}$ & $-0.39 \pm 0.02^{\mathrm{b}}$ & $10.35 \pm 0.87^{\mathrm{c}, \mathrm{d}}$ & $21.29 \pm 1.26^{\mathrm{d}, \mathrm{e}}$ \\
\hline & 5-CQA 90 & $24.91 \pm 1.45^{\mathrm{f}, \mathrm{g}}$ & $40.12 \pm 3.42^{\mathrm{f}}$ & $77.08 \pm 6.15^{\mathrm{c}, \mathrm{d}}$ & $2.67 \pm 0.19^{\mathrm{e}, \mathrm{f}}$ & $17.56 \pm 1.15^{\mathrm{e}, \mathrm{f}}$ & $19.05 \pm 1.03^{\mathrm{d}}$ \\
\hline & FA 90 & $28.04 \pm 1.76^{\mathrm{g}, \mathrm{h}}$ & $42.80 \pm 2.70^{\mathrm{f}, \mathrm{g}}$ & $82.35 \pm 7.15^{\mathrm{d}, \mathrm{e}}$ & $-0.86 \pm 0.06^{\mathrm{a}}$ & $8.49 \pm 0.83^{\mathrm{a}, \mathrm{b}}$ & $32.21 \pm 2.99^{\mathrm{f}, \mathrm{g}}$ \\
\hline \multirow[t]{9}{*}{ WPC } & Unmodified & $49.68 \pm 3.43^{j}$ & $59.62 \pm 4.14^{\mathrm{h}}$ & $92.77 \pm 6.22^{\mathrm{g}, \mathrm{h}}$ & $-0.85 \pm 0.05^{\mathrm{a}}$ & $13.35 \pm 1.07^{\mathrm{d}, \mathrm{e}}$ & $101.08 \pm 3.17^{\mathrm{j}}$ \\
\hline & Control 25 & $37.15 \pm 3.21^{\mathrm{i}}$ & $32.51 \pm 2.70^{\mathrm{d}, \mathrm{e}}$ & $95.01 \pm 7.38^{\mathrm{g}, \mathrm{h}}$ & $-0.40 \pm 0.02^{\mathrm{b}}$ & $8.58 \pm 0.54^{\mathrm{a}, \mathrm{b}}$ & $97.42 \pm 8.66^{\mathrm{j}}$ \\
\hline & Control 90 & $8.29 \pm 0.57^{\mathrm{a}}$ & $19.33 \pm 1.16^{\mathrm{b}, \mathrm{c}}$ & $94.31 \pm 6.55^{\mathrm{g}, \mathrm{h}}$ & $-1.18 \pm 0.03^{\mathrm{a}}$ & $8.77 \pm 0.63^{\mathrm{a}, \mathrm{b}}$ & $42.17 \pm 3.19^{\mathrm{h}, \mathrm{i}}$ \\
\hline & GCE 25 & $45.72 \pm 3.21^{\mathrm{j}}$ & $36.12 \pm 3.12^{\mathrm{e}, \mathrm{f}}$ & $91.63 \pm 4.47^{\mathrm{f,g}}$ & $0.20 \pm 0.01$ & $10.28 \pm 0.94^{\mathrm{c}, \mathrm{d}}$ & $91.55 \pm 8.73$ \\
\hline & GCE 90 & $13.78 \pm 1.12^{\mathrm{b}, \mathrm{c}}$ & $18.51 \pm 0.87^{\mathrm{b}}$ & $82.37 \pm 6.12^{\mathrm{d}, \mathrm{e}}$ & $1.94 \pm 0.12^{\mathrm{d}}$ & $23.32 \pm 1.17^{\mathrm{g}}$ & $35.20 \pm 5.48^{\mathrm{g}}$ \\
\hline & $\beta$-CD-HCAs 90 & $18.11 \pm 1.17^{\mathrm{c}, \mathrm{d}}$ & $21.68 \pm 2.08^{\mathrm{b}, \mathrm{c}}$ & $91.77 \pm 5.73^{\mathrm{f}, \mathrm{g}}$ & $-0.39 \pm 0.02^{\mathrm{b}}$ & $9.64 \pm 0.83^{\mathrm{b}, \mathrm{c}}$ & $40.39 \pm 2.32^{\mathrm{h}, \mathrm{i}}$ \\
\hline & CA 90 & $15.07 \pm 1.46^{\mathrm{c}}$ & $21.21 \pm 3.15^{\mathrm{b}, \mathrm{c}}$ & $89.06 \pm 7.89^{\mathrm{f}, \mathrm{g}}$ & $-0.99 \pm 0.06^{\mathrm{a}}$ & $18.44 \pm 2.17^{\mathrm{f}, \mathrm{g}}$ & $25.65 \pm 1.55^{\mathrm{e}, \mathrm{f}}$ \\
\hline & 5-CQA 90 & $12.17 \pm 0.98^{b, c}$ & $20.03 \pm 1.16^{\mathrm{b}, \mathrm{c}}$ & $80.11 \pm 4.27^{\mathrm{d}, \mathrm{e}}$ & $2.31 \pm 0.17^{\mathrm{e}}$ & $25.18 \pm 2.48^{\mathrm{g}}$ & $22.43 \pm 1.75^{\mathrm{d}, \mathrm{e}}$ \\
\hline & FA 90 & $18.45 \pm 1.34^{\mathrm{c}, \mathrm{d}}$ & $28.23 \pm 1.89^{\mathrm{d}}$ & $91.71 \pm 6.65^{\mathrm{f}, \mathrm{g}}$ & $-0.36 \pm 0.02^{\mathrm{b}}$ & $12.25 \pm 1.56^{\mathrm{d}, \mathrm{e}}$ & $47.64 \pm 3.6^{\mathrm{i}}$ \\
\hline \multirow[t]{9}{*}{ SPI } & Unmodified & $40.25 \pm 2.38^{\mathrm{i}, \mathrm{j}}$ & $62.61 \pm 4.76^{\mathrm{h}, \mathrm{i}}$ & $84.28 \pm 5.38^{\mathrm{e}, \mathrm{f}}$ & $3.05 \pm 0.28^{\mathrm{f}, \mathrm{g}}$ & $17.70 \pm 1.34^{\mathrm{e}, \mathrm{f}}$ & $71.34 \pm 6.43$ \\
\hline & Control 25 & $33.15 \pm 2.10^{\mathrm{h}}$ & $59.73 \pm 3.74^{\mathrm{h}}$ & $74.31 \pm 4.02^{\mathrm{c}}$ & $2.29 \pm 0.16^{\mathrm{e}}$ & $16.42 \pm 1.52^{\mathrm{e}, \mathrm{f}}$ & $30.58 \pm 2.71^{\mathrm{f}, \mathrm{g}}$ \\
\hline & Control 90 & $2.87 \pm 0.18$ & $8.74 \pm 0.76$ & $66.81 \pm 5.12^{\mathrm{b}, \mathrm{c}}$ & $1.71 \pm 0.11^{\mathrm{c}}$ & $15.80 \pm 2.10^{\mathrm{e}, \mathrm{f}}$ & $15.36 \pm 0.53^{\mathrm{b}}$ \\
\hline & GCE 25 & $35.39 \pm 2.08^{\mathrm{h}, \mathrm{i}}$ & $67.08 \pm 5.42^{\mathrm{i}}$ & $62.22 \pm 4.77^{\mathrm{b}}$ & $2.58 \pm 0.23^{\mathrm{e}, \mathrm{f}}$ & $16.28 \pm 1.78^{\mathrm{e}, \mathrm{f}}$ & $25.05 \pm 2.12^{\mathrm{e}, \mathrm{f}}$ \\
\hline & GCE 90 & $7.23 \pm 0.67^{\mathrm{a}}$ & $18.71 \pm 2.47^{\mathrm{b}}$ & $48.28 \pm 3.22^{\mathrm{a}}$ & $5.26 \pm 0.43$ & $18.90 \pm 1.34^{\mathrm{f}, \mathrm{g}}$ & $13.64 \pm 1.65^{\mathrm{a}, \mathrm{b}}$ \\
\hline & $\beta$-CD-HCAs 90 & $5.36 \pm 0.44$ & $12.82 \pm 1.66^{\mathrm{a}}$ & $65.19 \pm 4.87^{\mathrm{b}}$ & $3.47 \pm 0.26^{\mathrm{g}}$ & $14.70 \pm 1.17^{\mathrm{d}, \mathrm{e}}$ & $15.42 \pm 1.98^{\mathrm{b}}$ \\
\hline & CA 90 & $10.79 \pm 0.96^{\mathrm{b}}$ & $18.38 \pm 2.01^{\mathrm{b}}$ & $64.16 \pm 3.89^{\mathrm{b}}$ & $1.62 \pm 0.10^{\mathrm{c}}$ & $12.32 \pm 1.16^{\mathrm{d}, \mathrm{e}}$ & $12.39 \pm 1.08^{\mathrm{a}}$ \\
\hline & 5-CQA 90 & $10.18 \pm 1.26^{\mathrm{b}}$ & $13.10 \pm 1.56^{\mathrm{a}}$ & $40.62 \pm 5.28^{\mathrm{a}}$ & $3.05 \pm 0.25^{\mathrm{f}, \mathrm{g}}$ & $13.45 \pm 0.78^{\mathrm{d}, \mathrm{e}}$ & $11.03 \pm 0.87^{\mathrm{a}}$ \\
\hline & FA 90 & $11.65 \pm 1.96^{\mathrm{b}}$ & $22.43 \pm 3.52^{\mathrm{c}, \mathrm{d}}$ & $65.19 \pm 6.14^{b}$ & $1.55 \pm 0.18^{\mathrm{c}}$ & $13.18 \pm 1.51^{\mathrm{d}, \mathrm{e}}$ & $13.20 \pm 1.76^{\mathrm{a}, \mathrm{b}}$ \\
\hline
\end{tabular}

The results of both assays showed similar trends. Unmodified proteins revealed $\mathrm{DPPH}^{\circ}$ and $\mathrm{OH}^{*}$ radicals scavenging capacity at the level of 71.98 and $81.96 \%$ for EWP, 49.68 and $59.62 \%$ for WPC, and 40.25 and $62.61 \%$ for SPI, respectively (Table 3 ). The highest radical-scavenging capacity was observed for EWP, and this tendency was maintained also after heating the three proteins. Heating without HCAs resulted in the reduction of $\mathrm{DPPH}^{-}$and $\mathrm{OH}^{-}$radical-scavenging capacities for EWP to 20.55 and $38.83 \%$, for WPC to 8.29 and $19.33 \%$ and for SPI to 2.87 and $8.74 \%$, respectively. Proteins heated with HCAs formed products of interactions, which showed higher $\mathrm{DPPH}^{*}$ and $\mathrm{OH}^{*}$ radicals scavenge capacities than controls, in the range of 5.36-29.90\% for DPPH ${ }^{\circ}$ and $12.82-42.80 \%$ for $\mathrm{OH}^{*}$. It proved that even after interactions, HCAs maintained their high radical-scavenging activity and confirmed findings of many other studies on antioxidant activity of protein-HCA interaction products $[37,38]$.
Studies by Tsai et al. [38] and Budryn et al. [39] revealed that the temperature increase during the interactions results in a decrease in antioxidant activity, as for all proteins analyzed in this study. Such tendency is caused by degradation of polyphenols during heating, but also by degradation of sulfur-containing amino acids. Due to the fact that proteins interacted with $\beta$-CD-HCAs in much lesser extent than with other forms of HCAs, such products of interactions showed the radical-scavenging capacities similar to proteins heated alone, although statistical increase was observed $(p<0.05)$.

Color of proteins after interactions with HCAs

Among the unmodified protein isolates WPC exhibited the least amount of pigments (Table 3). Heating of proteins without HCAs caused darkening, and degradation of green, 
red or yellow pigments. The presence of HCAs during heating of proteins contributed to greater color changes. For all protein-GCE and protein-5-CQA interactions, a shift from green to red pigments was observed or the content of red pigments rose. Increased content of red pigments may be caused by the formation of new structures between amino acids and radical semiquinones derived from HCAs, which result in the formation of browning reaction products [40]. Among all products of protein-HCA interactions, the slightest color changes were caused by addition of HCAs in the form of inclusion complexes with $\beta-\mathrm{CD}$. This is a result of limited interactions of proteins with $\beta$-CD-HCAs [23]. After interactions of protein isolates with HCAs in the form of GCE, $L^{*}$ decreased and the order of darkening was: WPC $<$ EWP $<$ SPI. Darkening of protein-based films containing HCAs was earlier observed by Nuthong et al. [41] and Prodpran et al. [42]. The HCAs and SPI interactions at $90{ }^{\circ} \mathrm{C}$ decreased $L^{*}$ from the initial value of 84.28 to 48.28 , while SPI heated alone had $L^{*}=66.81$. Therefore, for SPI, those differences were highly significant $(p<0.005)$ and suggest the possibility of taking unattractive gray-brown color of heated food containing both SPI and free HCAs.

\section{Solubility of proteins after interactions with HCAs}

Except SPI (71.34 \%) unmodified protein isolates were completely soluble in water (Table 3 ). Along with protein modifications, reduction of their solubility was observed. Decrease of solubility covered the range of $2.65-81.10 \%$ for EWP, 3.62-77.81\% for WPC and 57.13-84.54\% for SPI. Depending on the type of protein, solubility decreased in the following order WPC $<$ EWP $<$ SPI and it was not correlated with AMM changes, which were the least for SPI. Thus, also other factors such as changes in isoelectric point, conformation and density of molecule could affect protein solubility [43]. Temperature rise during interactions contributed to greater solubility decrease. Depending on the form of HCAs, proteins solubility decreased in the following order: $\beta$-CD-HCAs $<$ GCE $<$ FA $<$ CA $<5$-CQA. Therefore, solubility reduction caused by interactions with HCAs was limited by formation of inclusion complexes of HCAs with $\beta$-CD.

\section{Conclusions}

The studies demonstrated that the addition of HCAs in free form to the solutions of protein isolates, such as EWP, WPC and SPI regardless heating causes an increase in molecular mass and degradation of essential amino acids as well as limits protein digestion compared with proteins processed without HCAs. Furthermore, it was reported that the HCAs presence during processing caused rise of $\mathrm{DPPH}^{\circ}$ and $\mathrm{OH}^{*}$ radical-scavenging capacity and color changes. Addition of HCAs in the form of inclusion complex with $\beta$-CD resulted in limitation of the protein-polyphenol interactions and as a consequence decreased changes in proteins in terms of nutritional and physicochemical properties. Taking into account (based on the literature data) high bioavailability of HCAs supplied in the form of inclusion complexes with $\beta$-CD, such encapsulation could be a promising solution for reducing unfavorable protein-polyphenol interactions during processing of foods enriched with HCAs.

Acknowledgments Authors are grateful for the financial support provided by National Center of Science (Project No. UMO-2011/03/B/NZ9/00745).

\section{Conflict of interest None}

Compliance with Ethics Requirements This article does not contain any studies with human or animal subjects.

Open Access This article is distributed under the terms of the Creative Commons Attribution License which permits any use, distribution, and reproduction in any medium, provided the original author(s) and the source are credited.

\section{References}

1. Rohn S, Rawel HM, Röber M, Kroll J (2005) Reactions with phenolic substances can induce changes in some physico-chemical properties and activities of bromelain - the consequences for supplementary food products. Int J Food Sci Technol 40:771-782

2. Henekamp JC, Bast A (2007) Food supplements and European regulation within a precautionary context: a critic and implications for nutritional, toxicological and regulatory consistency. Crit Rev Food Sci Nutr 47:267-285

3. Zhao M, Wahg H, Yang B, Tao H (2010) Identification of cyclodextrin inclusion complex of chlorogenic acid and its antimicrobial activity. Food Chem 120:1138-1142

4. Lou Z, Wang H, Zhu S, Ma C, Wang Z (2011) Antibacterial activity and mechanism of action of chlorogenic acid. J Food Sci 76:398-403

5. Sung WS, Lee DG (2010) Antifungal action of chlorogenic acid against pathogenic fungi, mediated by membrane disruption. Pure Appl Chem 82:219-226

6. Shi H, Dong L, Dang X, Liu Y, Jiang J, Wang Y, Lu X, Guo X (2013) Effect of chlorogenic acid on LPS-induced proinflammatory signaling in hepatic stellate cells. Inflamm Res 62:581-587

7. Satake T, Kamiya K, An Y, Oishi T, Yamamoto J (2007) The anti-thrombotic active constituents from Centella asiatica. Biol Pharm Bull 30:935-940

8. El-Medany A, Bassiouni Y, Khattab M, Mahesar A (2011) Chlorogenic acid as potential anti-inflammatory analgesic agent: an investigation of the possible role of nitrogen-based radicals in rats. Int J Pharmacol Toxicol Sci 1:24-33

9. Bassoli BK, Cassolla P, Borba-Murad GR, Constantin J, Salgueiro-Pagadigorria CL, Bazotte RB, da Silva RS, de Souza HM (2008) Chlorogenic acid reduces the plasma glucose peak in the oral glucose tolerance test: effects on hepatic glucose release and glycaemia. Cell Biochem Funct 26:320-328

10. Sato Y, Itagaki S, Kurokawa T, Ogura J, Kobayashi M, Hirano $\mathrm{T}$, Sugawara M, Iseki K (2011) In vitro and in vivo antioxidant 
properties of chlorogenic acid and caffeic acid. Int $\mathrm{J}$ Pharm 403:136-138

11. Cheng JC, Dai F, Zhou B, Yang L, Liu ZL (2007) Antioxidant activity of hydroxycinnamic acid derivatives in human low density lipoprotein: mechanism and structure-activity relationship. Food Chem 104:132-139

12. Lee KW, Lee HJ (2006) The roles of polyphenols in cancer chemoprevention. BioFactors 26:105-121

13. Silva BA, Ferreres F, Malva JO, Dias ACP (2005) Phytochemical and antioxidant characterization of Hypericum perforatum alcoholic extracts. Food Chem 90:157-167

14. Budryn G, Nebesny E, Rachwał-Rosiak D, Pałecz B, Hodurek P, Miśkiewicz K, Oracz J, Żyżelewicz D (2014) Inclusion complexes of $\beta$-cyclodextrin with chlorogenic acids (CHAs) from crude and purified aqueous extracts of green Robusta coffee beans (Coffea canephora L.). Food Res Int 61:202-213

15. Budryn G, Nebesny E, Rachwał-Rosiak D, Oracz J (2013) Fatty acids, essential amino acids, and chlorogenic acids profiles, in vitro protein digestibility and antioxidant activity of food products containing green coffee extract. Int Food Res J 20:2133-2144

16. Petzke KJ, Schuppe S, Rohn S, Rawel HM, Kroll J (2005) Chlorogenic acid moderately decreases the quality of whey proteins in rats. J Agric Food Chem 53:3714-3720

17. Bandyopadhyay P, Ghosh AK, Ghosh C (2012) Recent developments on polyphenol-protein interactions: effects on tea and coffee taste, antioxidant properties and the digestive system. Food Func 3:592-605

18. Ubbik J, Krüger J (2006) Physical approaches for the delivery of active ingredients in foods. Trends Food Sci Technol 17:244-254

19. Nasirullah Kumar P, Shariff R (2011) Development of nutraceutical carriers for functional food applications. Nutr Food Sci 41:34-43

20. Szejtli J, Szente L (2005) Elimination of bitter, disgusting tastes of drugs and foods by cyclodextrins. Eur J Pharm Biopharm 61:115-125

21. Gacche RN, Zore GB, Ghole VS (2003) Kinetics of inhibition of polyphenol oxidase mediated browning in apple juice by $\beta$-cyclodextrin and 1 -ascorbate-2-triphosphate. J Enzyme Inhib Med Chem 18:1-5

22. Paramera EI, Konteles SJ, Karathanos VT (2011) Stability and release properties of curcumin encapsulated in Saccharomyces cerevisiae, $\beta$-cyclodextrin and modified. Food Chem 125:913-922

23. Budryn G, Pałecz B, Rachwał-Rosiak D, Oracz J, Zaczyńska D, Belica S, Navarro-González I, Vegara Meseguer JM, PérezSánchez H (2015) Effect of inclusion of hydroxycinnamic and chlorogenic acids from green coffee bean in $\beta$-cyclodextrin on their interactions with whey, egg white and soy protein isolates. Food Chem 168:276-287

24. Rawel HM, Kroll J, Hohl UC (2001) Model studies on reactions of plant phenols with whey proteins. Nahrung 45:72-81

25. Official Journal of the European Communities, Annex, Determination of amino acid (1998) L 2560919

26. MacDonald-Wicks LK, Woog LG, Garg ML (2006) Methodology for the determination of biological antioxidant capacity in vitro: a review. J Sci Food Agric 86:2046-2056
27. Sudha G, Sangeetha Priya M, Indhu Shree R, Vadivukkarasi S (2011) In vitro free radical scavenging activity of raw pepino fruit (Solanum muricatum aiton). Int J Curr Pharm Res 3:137-140

28. Charurin P, Ames JM, del Castillo MD (2002) Antioxidant activity of coffee model systems. J Agric Food Chem 50:3751-3756

29. Færgemand M, Otte J, Qvist KB (1998) Crosslinking of whey proteins by enzymatic oxidation. J Agric Food Chem 46:1326-1333

30. Rawel HM, Rohn S, Kroll J (2003) Influence of a sugar moiety (rhamnosylglucoside) at 3-O position on the reactivity of quercetin with whey proteins. Int J Biol Macromol 32:109-120

31. Venkatachalam M, Sathe SK (2003) Phaseolin in vitro pepsin digestibility: role of acids and phenolic compounds. J Agric Food Chem 51:3466-3472

32. Narita Y, Inouye K (2011) Inhibitory effects of chlorogenic acids from green coffee beans and cinnamate derivatives on the activity of porcine pancreas $\alpha$-amylase isozyme I. Food Chem 127:1532-1539

33. Zduńczyk Z, Frejnagel S, Wróblewska M, Juśkiewicz J, Oszmiański J, Estrella I (2002) Biological activity of polyphenol extracts from different plant sources. Food Res Int 35:183-186

34. Rohn S, Petzke KJ, Rawel HM, Kroll J (2006) Reactions of chlorogenic acid and quercetin with a soy protein isolate-influence on the in vivo food protein quality in rats. Mol Nutr Food Res 50:696-704

35. Rawel HM, Czajka D, Rohn S, Kroll J (2002) Interactions of different phenolic acids and flavonoids with soy proteins. Int J Biol Macromol 30:137-150

36. Budryn G, Rachwał-Rosiak D (2013) Interactions of hydroxycinnamic acids with proteins and their technological and nutritional implications. Food Rev Int 29:217-230

37. Bassil D, Makris DP, Kefalas P (2005) Oxidation of caffeic acid in the presence of L-cysteine: isolation of 2-S-cysteinylcaffeic acid and evaluation of its antioxidant properties. Food Res Int 38:395-402

38. Tsai PJ, She CH (2006) Significance of phenol-protein interactions in modifying the antioxidant capacity of peas. J Agric Food Chem 54:8491-8494

39. Budryn G, Nebesny E, Rachwał D (2014) Pepsin digestibility and antioxidant activity of egg white protein in model systems with green coffee extract. Int J Food Prop 17:1529-1546

40. Namiki M, Yabuta G, Koizumi Y, Yano M (2001) Development of free radical products during the greening reaction of caffeic acid esters (or chlorogenic acid) and a primary amino compound. Biosci Biotechnol Biochem 65:2131-2136

41. Nuthong P, Benjakul S, Prodpran T (2009) Effect of phenolic compounds on the properties of porcine plasma protein-based film. Food Hydrocoll 23:736-741

42. Prodpran T, Benjakul S, Phatcharat S (2012) Effect of phenolic compounds on protein cross-linking and properties of film from fish myofibrillar protein. Int J Biol Macromol 51:774-782

43. Rawel HM, Rohn S, Kruse HP, Kroll J (2002) Structural changes induced in bovine serum albumin by covalent attachment of chlorogenic acid. Food Chem 78:443-455 